\title{
Fluorescent components and spatial patterns of chromophoric dissolved organic matters in Lake Taihu, a large shallow eutrophic lake in China
}

\author{
Bo Yao ${ }^{1}$ - Chunming $\mathrm{Hu}^{2} \cdot{\text { Qingquan } \mathrm{Liu}^{3}}^{3}$
}

Received: 24 March 2016/Accepted: 23 August 2016 / Published online: 1 September 2016

(C) Springer-Verlag Berlin Heidelberg 2016

\begin{abstract}
Water samples at both surface and bottom layers were taken from 102 sites in Lake Taihu to study the fluorescent components and spatial patterns of chromophoric dissolved organic matters (CDOM). Three-dimensional excitation-emission matrix data obtained from the samples were analyzed by parallel factor approach in which four humiclike and two protein-like fluorescent components (named C1-C6) were identified. The results showed that fluorescence intensities were higher in the northern and western lake regions, and notable declines of fluorescence maxima $\left(F_{\max }\right)$ were observed from the northwest to the center and then to the southeast of the lake. Calculated biological index (BIX) values ranged from 0.88 to 1.44 and humification index (HIX) values from 0.64 to 3.37 for all the samples. The spatial variations of BIX and HIX values suggested stronger allochthonous CDOM characteristics in Zhushan Bay and the western area and autochthonous characteristics in the southern and eastern areas. Vertically, the average $F_{\max }$ value of the surface samples was about $6 \%$ less than that of the bottom samples, but noticeable variations existed among different sampling sites and components. These distribution characteristics of
\end{abstract}

Responsible editor: Philippe Garrigues

Bo Yao

yaobo@imech.ac.cn

1 Key Laboratory for Mechanics in Fluid Solid Coupling Systems, Institute of Mechanics, Chinese Academy of Sciences, Beijing 100190, China

2 State Key Laboratory of Environment Criteria and Risk Assessment, Chinese Research Academy of Environmental Sciences, Beijing 100012, China

3 Department of Mechanics, School of Aerospace Engineering, Beijing Institute of Technology, Beijing 100081, China
CDOM were mainly attributed to the spatial heterogeneity of sources and wind-induced transportation process. Interestingly, the $\mathrm{C} 6$ component $\left(\mathrm{Ex}_{\max } / \mathrm{Em}_{\max }=250 /\right.$ $455 \mathrm{~nm}$ ) seemed to be unique in samples from Zhushan Bay and probably resulted from the discharge of the Taige River. Therefore, it could be used as an indicator of point-source discharge and a tracer to study the fate of CDOM in the lake.

Keywords PARAFAC · CDOM · Spatial heterogeneity · Vertical difference $\cdot$ Hydrodynamics

\section{Introduction}

Dissolved organic matter (DOM) plays critical roles in eutrophic lakes, and its concentration and composition can both directly and indirectly influence the physical, chemical, and biological processes of nutrient cycling as well as the development of phytoplankton blooms (Stedmon et al. 2003; Biers et al. 2007). High spatial heterogeneity of DOM in large lakes exists as a result of multiple sources, complex chemical compositions and structures, and variable biogeochemical reactions. Therefore, knowledge of it is of vital importance in lake management and protection and has been of concern for the past several decades.

Chromophoric dissolved organic matter (CDOM) is the colored fraction of DOM, which mainly originates from the decomposition of plant matter such as phytoplankton algae and macrophyte by microorganisms within the aquatic environment (autochthonous), as well as through the transport of partially degraded organic material from rivers and the surrounding terrestrial environment (allochthonous) (Henderson et al. 2008, Williams et al. 2010, Yao et al. 2011). It consists of complex components such as aromatics, carbohydrates, humic and fulvic acids, and proteinaceous substances, and is hard to 
trace using regular chemical measurements. Fluorescence spectroscopy has been shown to be an efficient and effective approach to characterize CDOM, and the three-dimensional excitation-emission matrices (3DEEMs) that can be obtained from fluorescence measurements coupled with parallel factor (PARAFAC) analysis have been extensively applied to evaluate the composition, source, and fate of CDOM in various aquatic systems (Coble 1996; Stedmon and Markager 2005a; Murphy et al. 2013; Zhou et al. 2015a).

Lake Taihu is a large, shallow, eutrophic lake in the Yangtze Delta of China, which is located between $30^{\circ} 55^{\prime}$ $40^{\prime \prime}-31^{\circ} 32^{\prime} 58^{\prime \prime} \mathrm{N}$ and $119^{\circ} 52^{\prime} 32^{\prime \prime}-120^{\circ} 36^{\prime} 10^{\prime \prime} \mathrm{E}$ (Qin et al. 2007), and has a surface area of about $2338 \mathrm{~km}^{2}$ and mean depth of $1.9 \mathrm{~m}$ (Zhang et al. 2011). The lake is connected to a very complex network consisting of 172 rivers or channels (Qin et al. 2007), of which most are distributed in the western and northwestern parts of the lake basin, and water discharge mainly goes through Taipu River in the southeast of the lake into the East China Sea. Taihu Basin is a highly developed area in China, with high population density, urbanization, and economic development (Qin et al. 2007). The rapid increase in the amount of sewage discharged into Lake Taihu since the 1980s has led to high loads of nutrients and CDOM in the lake, especially in the northern and northwestern regions where large terrestrial and riverine inputs enter, making the lake serve as a repository for sewage from nearby urban households as well as industrial and agricultural activities (Qin et al. 2010). Heavy algal blooms mainly caused by Microcystis spp. have frequently occurred in the recent decades, especially in the hyper-eutrophic lake areas such as Meiliang Bay, Wuli Bay, and Zhushan Bay, where annual cyanobacterial blooms occur from May to October and in situ production from the degradation of phytoplankton becomes one of the dominant sources of CDOM (Zhang et al. 2009a, Zhou et al. 2015b). In addition, Lake Taihu has a long water retention time of about 309 days, causing the lake to act as a large bio-reactor for CDOM degradation before upstreamderived CDOM is discharged downstream, resulting in the degradation of young, fresh CDOM and leaving refractory material for downstream transport (Zhang et al. 2014). Both microbial activity and photochemical process can alter the compositions and biological availability of CDOM, suggesting that its lability might correspondingly decrease during the water translocation processes (Hood et al. 2009). As a result, these variations in sources and biogeochemical reactions lead to a high spatial heterogeneity of CDOM characteristics in the water of Lake Taihu (Yao et al. 2011, Zhang et al. 2011, Zhou et al. 2016a), and accurate interpretations of it are crucial and meaningful to the understanding of water quality issues in the lake.

In some previous studies (Yao et al. 2011, Zhang et al. 2011, Zhou et al. 2015c), the spatial and temporal variations as well as probable sources of CDOM in Lake Taihu were discussed. However, these studies were mainly based on water samples from the lake surface, and there is still a lack of information on the distribution of CDOM as a function of depth. It is of great interest whether or not there are differences in the vertical distribution of CDOM characteristic in such a shallow lake without temperature stratification (Qin et al. 2007). In fact, environmental factors such as solar irradiance, dissolved oxygen (DO), and phytoplankton are not uniformly distributed along the depth (Yang et al. 2007; Wu and Kong 2009), which are closely related to the fate of CDOM (such as photochemical and/or biological degradations) in the water and may lead to vertical heterogeneity. Other factors such as hydrodynamic conditions (e.g., wind-induced wave and current) also play important roles in the spatial distribution of CDOM in the lake (Wu et al. 2015, Zhou et al. 2016b) and need to be further discussed as well.

The main aims of this study are to (1) characterize fluorescent components of CDOM in Lake Taihu by PARAFAC analysis based on water samples taken from both surface and bottom layers; (2) inspect both horizontal and vertical distributions and sources of CDOM in the lake; and (3) discuss factors that influence the spatial pattern of CDOM, including sources and hydrodynamic conditions.

\section{Materials and methods}

\section{Sample collection and preparation}

Water samples were collected from 102 sites (shown in Fig. 1) in Lake Taihu in early September 2013. Both surface (about $0.1 \mathrm{~m}$ below surface) and bottom (about $0.1-0.3 \mathrm{~m}$ above bottom) water samples were collected using a 2-L plastic sampler and stored on ice while in the field. DO of each sample was determined immediately after sampling by a portable DO meter (HQ30, Hach Company, USA).

All water samples were filtered at low pressure first through a Whatman GF/F filter $(0.7 \mu \mathrm{m})$ and then through a 25 -mm Millipore cellulose membrane filter $(0.22 \mu \mathrm{m})$ into glass bottles pre-combusted at $550{ }^{\circ} \mathrm{C}$ for $8 \mathrm{~h}$, and stored in a refrigerator at $4{ }^{\circ} \mathrm{C}$ before measurement (Zhang et al. 2011).

\section{Three-dimensional fluorescence measurement}

Excitation-emission matrixes (EEMs) of CDOM were measured using a Hitachi F-7000 fluorescence spectrometer (Hitachi High-Technologies, Japan) with a $150-\mathrm{W}$ xenon lamp. The scans ranged from 200 to $400 \mathrm{~nm}$ on the excitation side and from 220 to $600 \mathrm{~nm}$ on the emission side, with 5-and 2-nm intervals for excitation and emission, respectively. The scanning speed was $1200 \mathrm{~nm} \mathrm{~min}{ }^{-1}$, and the voltage for the photomultiplier tube (PMT) was set to $700 \mathrm{~V}$. Blank EEMs of 
Fig. 1 Sampling sites in Lake Taihu, China. Both surface and bottom water samples were taken at the 102 sites (nos. 1-102) in early September 2013. There were also three samples (nos. 103-105) obtained from the Taige River. The lake was divided (by the gray dashed lines) into seven areas: Meiliang Bay (MB),

Gonghu Bay (GB), Zhushan Bay (ZB), western lake (WL), southern lake (SL), eastern lake $(\mathrm{EL})$, and center lake (CL)

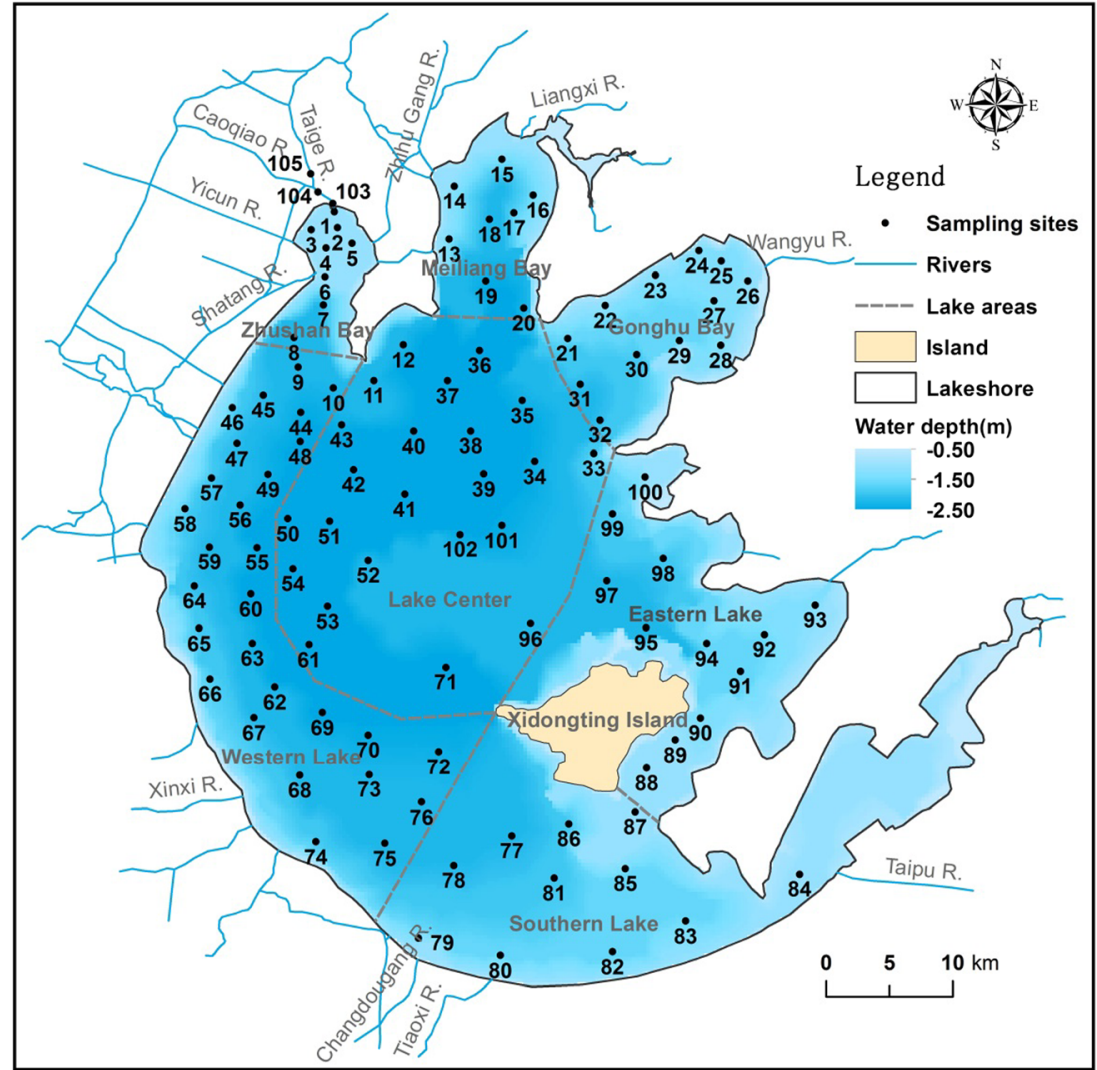

Milli-Q water were also recorded and used to reduce the water Raman scatter peaks via spectral subtraction.

Correction of instrumental response was conducted according to the procedure recommended by Hitachi (Hitachi F-7000 Instruction Manual) on both the excitation and emission sides. Absorbance spectra ranging from 200 to $600 \mathrm{~nm}$ were used for correction of inner filtering effects in the EEMs (Mobed et al. 1996), which were collected for all samples using a UV-vis spectrophotometer (UV2600, Shimadzu Corporation, Japan). Measured EEMs were corrected for absorbance by multiplying each value in the EEMs with a correction factor to eliminate the inner-filter effects (McKnight et al. 2001). Rayleigh and Raman scatter effects were removed by a MATLAB toolbox drEEM (Ver. 0.20) written by Murphy et al. (2013).

\section{PARAFAC modeling}

PARAFAC analysis was carried out using the MATLAB toolbox drEEM (Ver. 0.20) according to Murphy et al. (2013), in which the basic principles and main steps for PARAFAC modeling were given. Faulty data of excitation wavelengths below $220 \mathrm{~nm}$ and emission wavelengths below $250 \mathrm{~nm}$ in the EEMs were eliminated due to the unreliable signals present in these regions. Outlier tests were carried out to remove samples which could adversely affect the modeling. PARAFAC models with different numbers of components (4-7) were fitted and validated through a four-split analysis to find out the most reasonable number of fluorescent components.

\section{Calculation of fluorescence indices}

Two fluorescence indices were calculated to better understand the composition and distribution of CDOM characteristics. The humification index (HIX) is defined as the ratio of two areas $(H / L)$ for the emission spectrum at the excitation wavelength of $255 \mathrm{~nm}$ ( $254 \mathrm{~nm}$ in the literature), in which the ranges of emission wavelengths were 435-480 nm for $H$ and 300-345 $\mathrm{nm}$ for $L$ (Zsolnay et al. 1999). HIX indicates the aromaticity degree of CDOM, with larger values corresponding to greater fluorescence intensity at longer wavelength and thus to the presence of more conjugated aromatics. The biological index (BIX) is calculated as the ratio of fluorescence intensity emitted at 380 and $430 \mathrm{~nm}$ both excited at $310 \mathrm{~nm}$, which increases with increasing CDOM input from autochthonous biological activity in water samples, and larger values indicate CDOM with stronger endogenous characteristics (Huguet et al. 2009).

\section{Measurements of other water quality parameters}

Other water quality parameters such as total nitrogen (TN), total dissolved nitrogen (TDN), nitrate $\left(\mathrm{NO}_{3}{ }^{-}\right)$, ammonia 
Fig. 2 Examples of EEMs for water samples from different areas of Lake Taihu: a lake center; b southern lake; c Meiliang Bay; d Zhushan Bay; e Gonghu Bay; f western lake. Contour was fluorescence intensity (a.u.)
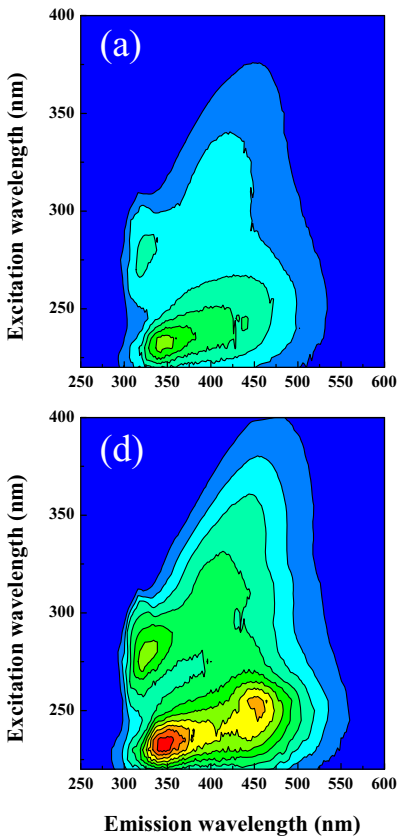

Emission wavelength (nm)
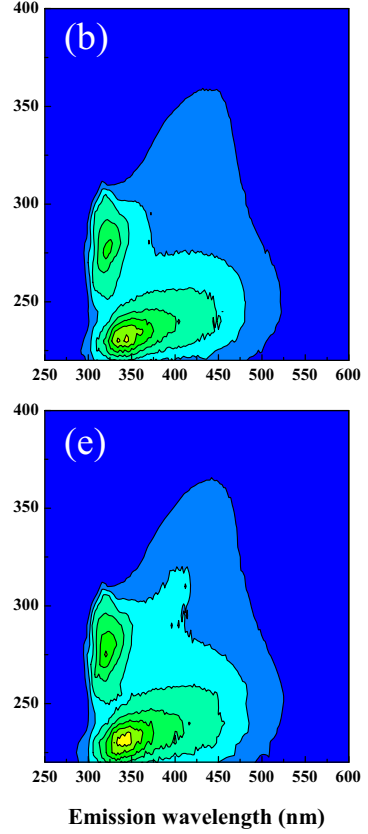
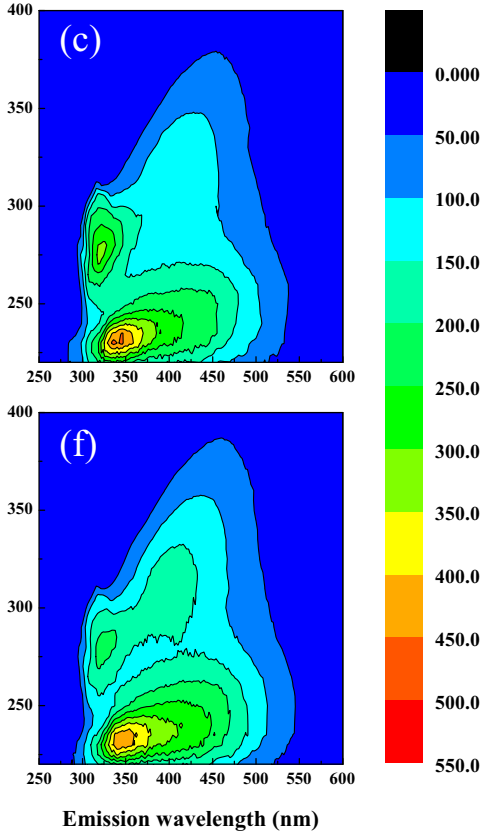

nitrogen $\left(\mathrm{NH}_{4}{ }^{+}\right)$, total phosphorus (TP), total dissolved phosphorus (TDP), and dissolved organic carbon (DOC) were also determined. Except for TN and TP, all parameters were measured after the water samples were filtered first through a Whatman GF/F filter $(0.7 \mu \mathrm{m})$ and then through a $25-\mathrm{mm}$ Millipore cellulose membrane filter $(0.22 \mu \mathrm{m})$.
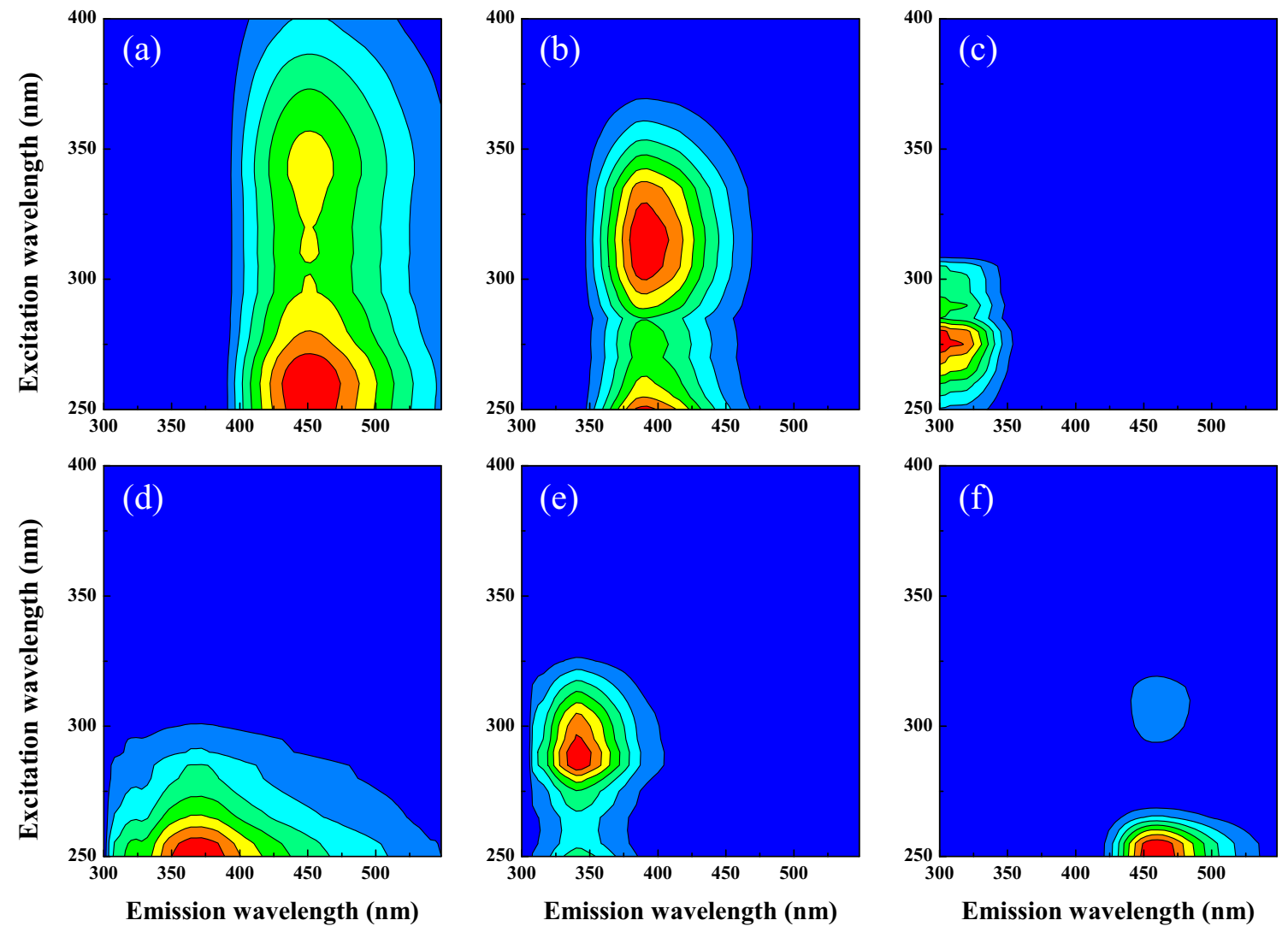

Fig. 3 Fingerprint maps for the six fluorescent components (C1-C6) identified by the six-component PARAFAC model validated by a four-split analysis, in which a-f were for $\mathrm{C} 1-\mathrm{C} 6$, respectively 

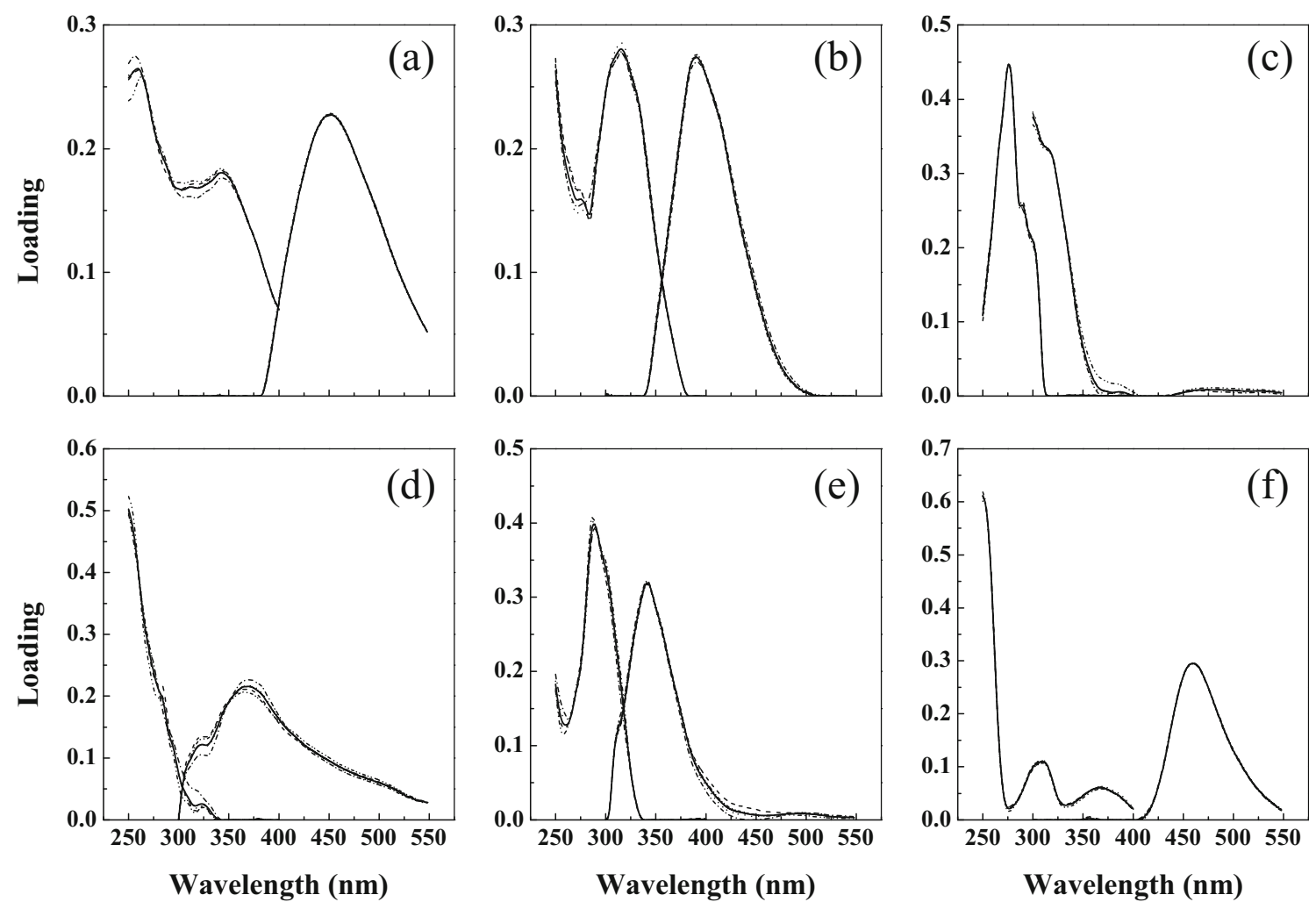

Fig. 4 Spectral loadings for the six fluorescent components identified by the PARAFAC model validated through a four-split analysis, in which $\mathbf{a}-\mathbf{f}$ were for $\mathrm{C} 1-\mathrm{C} 6$, respectively, and different line types represented different splits

TN and TOC were analyzed on a TOC/TN Analyzer (Multi N/C 2100, Analytik Jena Company, Germany). The other parameters were analyzed on a UV-vis spectrophotometer (Shimadzu UV2600), in which TP, $\mathrm{NO}_{3}{ }^{-}$, and $\mathrm{NH}_{4}{ }^{+}$were determined by the molybdenum blue spectrophotometry, UV spectrophotometry, and Nessler's reagent spectrophotometry methods, respectively.

\section{Statistical analyses and plots}

In order to discuss the horizontal variations of $\mathrm{CDOM}$ characteristics, the whole lake areas were divided into seven sub-regions, which are center lake (CL), eastern lake (EL), western lake (WL), southern lake (SL), Meiliang Bay (MB), Gonhu Bay (GB), and Zhushan Bay (ZB), respectively (see Fig. 1).

The coefficient of variation (CV), also called relative standard deviation (RSD), is used to describe the differences in CDOM characteristics between the surface and bottom water samples. It is defined as the ratio of standard deviation $(\sigma)$ to the mean $(\mu)$ :

$$
C V=\frac{\sigma}{\mu} \times 100 \%
$$

and larger $\mathrm{CV}$ values indicate greater variations between the samples from the surface and bottom layers.
Statistical analyses including calculation of mean values, variations, and regression coefficients were performed using MATLAB 2013a (MathWorks, Inc.). Regression and correlation analyses were used to examine the relationships between CDOM components and the other water quality parameters. Plots were generated by ArcMap 10.0 (ESRI Inc.) and Origin Pro 8.5 (OriginLab Corp.).

\section{Results}

\section{General characteristics for EEMs of DOM}

EEMs of all the water samples were analyzed, and four typical fluorescence peaks could be characterized from the contour plots using the "peak picking" technique, which comprised two humic-like and two protein-like fluorescent peaks (Coble 1996). The first humic-like fluorescent peak was located in the ultraviolet band with excitation wavelengths ranging from 230 to $250 \mathrm{~nm}$ and emission wavelengths from 400 to $460 \mathrm{~nm}$, and the second was in the visible range $(E x=280-310 \mathrm{~nm}$, $\mathrm{Em}=380-455 \mathrm{~nm})$. The first protein-like fluorescent peak had shorter excitation wavelengths $(E x=230-240 \mathrm{~nm}$, $\mathrm{Em}=330-350 \mathrm{~nm})$, and the second had longer excitation wavelengths $(E x=270-290 \mathrm{~nm}, E \mathrm{~m}=300-310 \mathrm{~nm})$. Examples of EEMs for water samples from different areas of 
Table 1 Maxima of excitation and emission of the six fluorescent components identified by the PARAFAC model in this study and comparisons with previous studies

\begin{tabular}{|c|c|c|c|c|}
\hline Component & $\mathrm{Ex}_{\max } / \mathrm{nm}$ & $\mathrm{Em}_{\max } / \mathrm{nm}$ & Comparison with other similar studies & Origin and description \\
\hline $\mathrm{C} 1$ & $260 / 340$ & 452 & $\begin{array}{l}\text { C peak 320-360/420-480 (Coble 1996) } \\
\text { C1: 270(265)/453 (Zhang et al. 2009b) } \\
\text { C1: 270(365)/470 (Chari et al. 2012) } \\
\text { C3: 260(355)/470 (Zhou et al. 2016a) }\end{array}$ & Terrestrial-like humic substances \\
\hline $\mathrm{C} 2$ & $275 / 315$ & 392 & $\begin{array}{l}\text { M peak: 290-310/370-410 (Coble et al. 1998) } \\
\text { N peak: 280/370 (Coble et al. 1998) } \\
\text { C3: 295/398 (Stedmon \&Markager 2005a) } \\
\text { C4: 290/405 (Chari et al. 2012) } \\
\text { C2: 315/418 (Murphy et al. 2013) }\end{array}$ & $\begin{array}{l}\text { Marine humic-like substances } \\
\text { (phytoplankton degradation) }\end{array}$ \\
\hline $\mathrm{C} 3$ & $275 / 290$ & 302 & $\begin{array}{l}\text { B peak 275/305-310 (Coble 1996) } \\
\text { C4: 275/306 (Stedmon \&Markager 2005a) } \\
\text { C7: 270/299 (Yamashita et al. 2008) } \\
\text { C2: 275/<300 (Zhang et al. 2009b) } \\
\text { C3: 270/295 (Chari et al. 2012) }\end{array}$ & Tyrosine-like, protein-like \\
\hline $\mathrm{C} 4$ & 250 & 372 & $\begin{array}{l}\text { A peak 230-260/380-460 (Coble et al. 1998) } \\
\text { C3: <250(305)/412 (Stedmon \&Markager 2005b) } \\
\text { C4: } 250(320) / 370 \text { (Murphy et al. 2008) } \\
\text { C6: } 250 / 360 \text { (Jørgensen et al. 2011) } \\
\text { C5: 240/384.5 (Nimptsch et al. 2015) }\end{array}$ & Terrestrial-like humic substances \\
\hline $\mathrm{C} 5$ & 290 & 340 & $\begin{array}{l}\text { T peak: 225-230(275)/340-350 (Coble et al. 1998) } \\
\text { C6: 280/338 (Stedmon \&Markager 2005b) } \\
\text { C4: 280/318 (Yamashita et al. 2008) } \\
\text { C5: 275/325 (Chari et al. 2012) }\end{array}$ & Tryptophan-like, protein-like \\
\hline C6 & 255 & 455 & $\begin{array}{l}\text { C1: }<250 / 448 \text { (Stedmon \&Markager 2005b) } \\
\text { C1: }<260 / 458 \text { (Yamashita et al. 2008) } \\
\text { C3: }<250 / 432 \text { (Osburn et al. 2011) } \\
\text { C2: }<250 / 440 \text { (Chari et al. 2012) }\end{array}$ & $\begin{array}{l}\text { Terrestrial humic-like substances } \\
\text { UV humic-like }\end{array}$ \\
\hline
\end{tabular}

Lake Taihu are given in Fig. 2. The contour maps for EEMs of samples from each area were similar, and the two protein-like fluorescence peaks were prominent. The humic-like peaks, however, varied between the lake areas, especially the ultraviolet humic component which was more significant in Zhushan Bay than in the other lake areas. Red shifts for the fluorescence peaks were also unique in the EEMs of Zhushan Bay when compared to the others. Additionally, the fluorescence peak intensity of the sample from the center of the lake was relatively low in comparison.

\section{PARAFAC modeling}

The results of PARAFAC analysis suggested that the sixcomponent model provided the best result statistically and could explain more than $99.6 \%$ of the EEMs. The fingerprint maps of the six identified components (represented as C1-C6) and their excitation and emission spectra are presented in Fig. 3 and Fig. 4, respectively. Characteristics of the excitation and emission features for these components are provided in Table 1, with information on similar components reported in related works by other researchers.

The six identified components consist of four humic-like and two protein-like components. C1 (Ex $x_{\max } /$ $\left.\mathrm{Em}_{\max }=260(340) / 452 \mathrm{~nm}\right)$ and C6 $\left(\mathrm{Ex}_{\max } / \mathrm{Em}_{\max }=255 /\right.$
$455 \mathrm{~nm}$ ) are similar to that of terrestrial humic-like materials which were found in many natural water bodies in previous works based on peak-picking and PARAFAC analysis (Coble 1996, Coble et al. 1998, Osburn et al. 2011, Zhou et al. 2016a), and were characterized as peak $\mathrm{C}$ by Coble et al. (1998). $\mathrm{C} 4\left(\mathrm{Ex}_{\max } / \mathrm{E}_{\max }=250 / 372 \mathrm{~nm}\right)$ is probably from terrestrial humic-like substances as well and was characterized as peak A (Coble et al. 1998). C2 $\left(\mathrm{Ex}_{\max } / \mathrm{Em}_{\max }=275(315) /\right.$ $392 \mathrm{~nm}$ ) is similar to that of humic substances derived from biological degradations, which is also called marine humiclike substances in seawater and was characterized as peak $M$ by Coble et al. (1998). C3 $\left(\mathrm{Ex}_{\max } / \mathrm{Em}_{\max }=275(290) / 302 \mathrm{~nm}\right)$ and $\mathrm{C5}\left(\mathrm{Ex}_{\max } / \mathrm{Em}_{\max }=290 / 340 \mathrm{~nm}\right)$ represent protein-like fluorophores, which are similar to tyrosine-like (peak B) and tryptophan-like (peak T) fluorophores, respectively (Coble et al. 1998).

\section{Areal distributions}

Contour maps for the vertically averaged fluorescence intensity maxima ( $F_{\max }$, in unit of a.u.) of the six components are shown in Fig. 5. It is clear that $F_{\max }$ values are larger in the northern (Zhushan Bay and Meiliang Bay) and western areas and smaller in the center, eastern, and southern areas. Notable declines in $F_{\max }$ values 
Fig. 5 Contour maps of fluorescence intensity maxima (vertically averaged, in unit of a.u.) for the six fluorescent components, in which a-f were for $C 1-C 6$, respectively

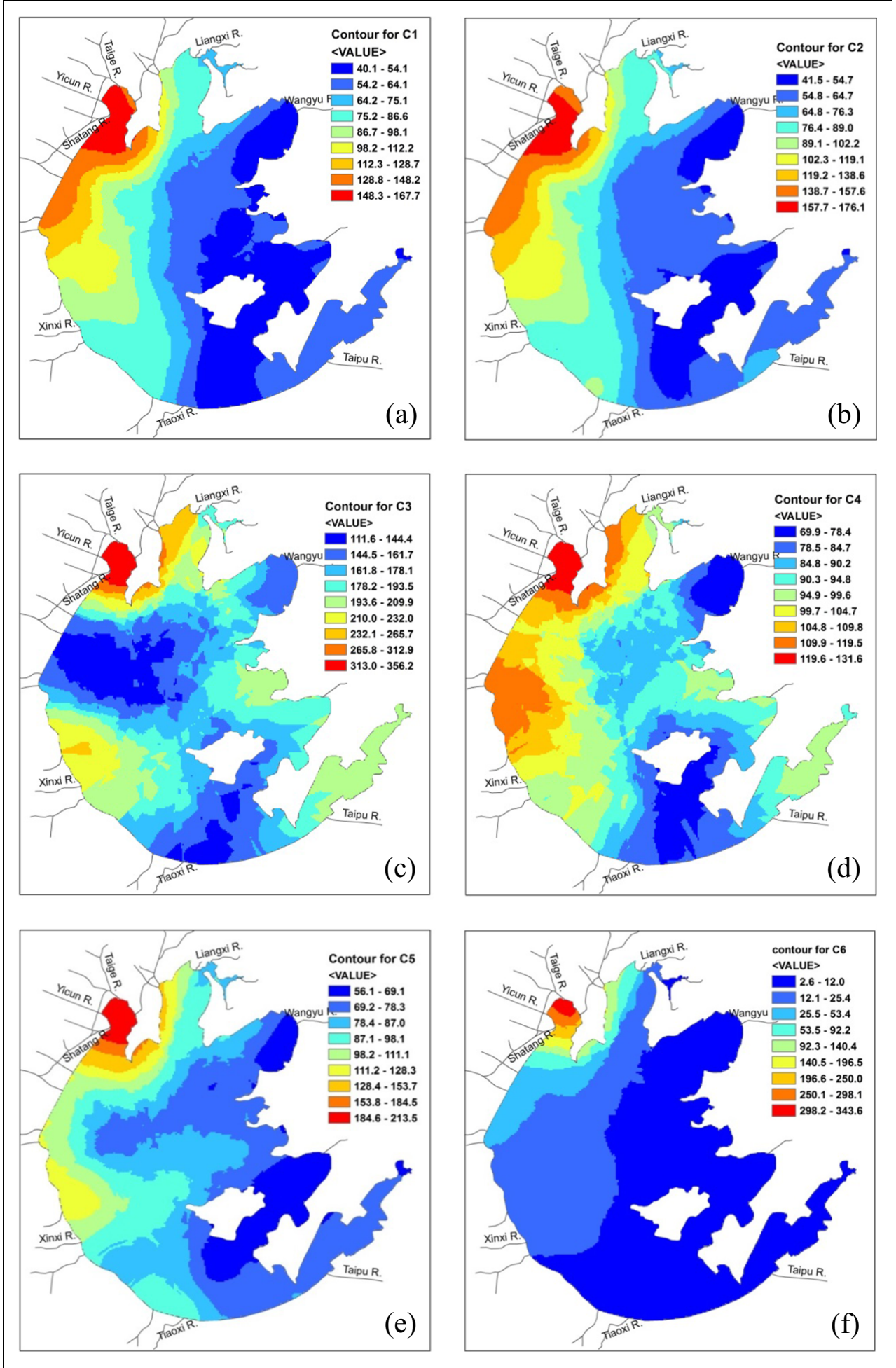

(especially for $\mathrm{C} 1, \mathrm{C} 2$, and $\mathrm{C} 6$ ) are observed from the northwest to the center and then to the southeast of the lake.

The average $F_{\max }$ values of each component from different lake areas are shown in Fig. 6. It is suggested that water samples from the three bays ( $\mathrm{ZB}, \mathrm{MB}, \mathrm{GB})$ generally have higher fluorescence intensities than those from the other regions. In particular, samples from Zhushan Bay appear to have markedly higher fluorescence intensity than the others. It is also very interesting that the intensity of C6 only seems to be notable in samples from Zhushan Bay, exhibiting a large gradient from 
Fig. 6 Average intensity maxima of fluorescent components ( $\mathrm{Cl}$ C6) for surface (a) and bottom (b) water samples from different lake areas: center lake $(C L)$, eastern lake $(E L)$, Gonghu Bay $(G B)$, Meiliang Bay $(M B)$, southern lake $(S L)$, western lake $(W L)$, and Zhushan Bay $(Z B)$

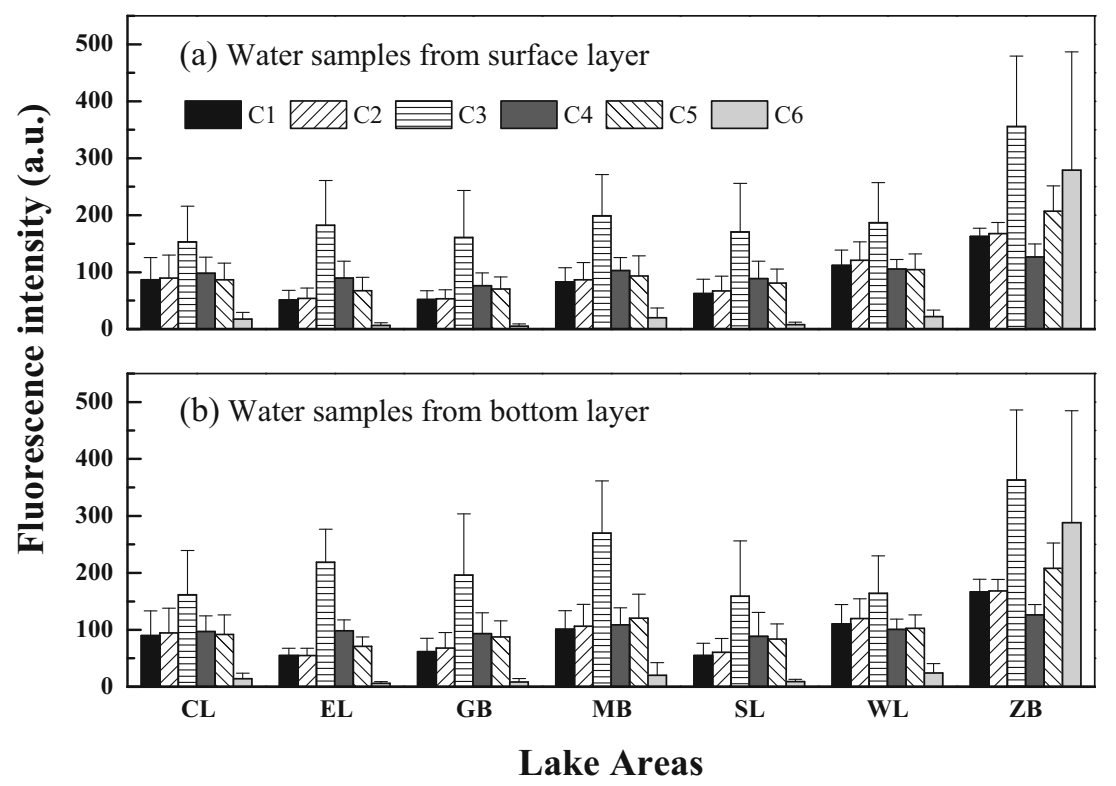

the mouth of the Taige River to the open lake area in the bay and becoming much lower outside the bay.

\section{Variations with depth}

The calculated CV values for the six components in different lake areas are presented in Table 2. CV values for C6 are greater than those of the other components, indicating larger differences between the surface and bottom samples. C4 shows the next highest variability with an average value of $23.4 \%$, about half that of C6 (41.5\%). The other components have very similar CV values. Of the seven lake areas, Gonghu Bay has the largest $\mathrm{CV}$ value of $35.7 \%$, followed by Meiliang Bay $31.8 \%$ and then by center lake, southern lake, and eastern lake, with CV values all around $25 \%$. Western lake has much smaller CV values (11.3\%), and Zhushan Bay has the smallest $(4.6 \%)$. Generally, the differences in $F_{\max }$ values between water samples obtained from the two vertical layers are smaller than those in the horizontal direction. In addition, $F_{\text {max }}$ values in the surface samples are a little smaller (about

Table 2 Coefficient of variation $(\mathrm{CV}, \%)$ values of vertical distribution for the six fluorescent components in different lake regions

\begin{tabular}{lrrrrrrr}
\hline Lake area & C1 & C2 & C3 & C4 & C5 & C6 & Average \\
\hline Center lake & 24.2 & 23.6 & 28.2 & 20.6 & 22.1 & 41.0 & 26.6 \\
Eastern lake & 13.0 & 13.7 & 19.8 & 16.3 & 14.1 & 55.4 & 22.1 \\
Gonghu Bay & 18.8 & 22.4 & 44.0 & 24.6 & 30.3 & 73.9 & 35.7 \\
Meiliang Bay & 25.2 & 28.5 & 30.3 & 26.4 & 28.4 & 52.0 & 31.8 \\
Southern lake & 19.6 & 19.7 & 20.6 & 19.8 & 19.7 & 44.4 & 24.0 \\
Western lake & 8.2 & 7.9 & 13.4 & 8.7 & 9.5 & 20.3 & 11.3 \\
Zhushan Bay & 5.7 & 3.3 & 3.1 & 4.3 & 3.1 & 8.3 & 4.6 \\
Average & 17.2 & 17.5 & 23.4 & 17.3 & 18.3 & 41.5 & 22.5 \\
\hline
\end{tabular}

$6 \%$ in average) than those in the bottom layer (see Fig. 6 and Table 2), which is not significant if the measuring errors are considered. However, it is still noticeable as the $\mathrm{CV}$ values range from 0.04 to $141 \%$ (relative errors range from -45 to $21 \%$ ) among distinct components and sampling sites, still suggesting noteworthy vertical heterogeneity.

\section{Fluorescence indices}

The calculated BIX values range from 0.89 to 1.44 with an average of $1.06 \pm 0.10$ for all the water samples from the surface layer, and from 0.88 to 1.44 with an average of $1.07 \pm 0.11$ for those from the bottom. The corresponding HIX values for the surface and bottom samples range from 0.83 to 3.37 with an average of $1.55 \pm 0.60$, and from 0.64 to 3.30 with an average of $1.55 \pm 0.60$, respectively. No obvious differences are found in the average BIX and HIX values between the surface and bottom samples. The average of the two fluorescence indices for different lake areas are shown in Fig. 7. It could be seen that spatial differences in the fluorescence indices in the lake are notable. Zhushan Bay has the smallest BIX value and southern lake has the largest, whereas Zhushan Bay has the largest HIX value and eastern lake has the smallest.

\section{Relationships with water quality parameters}

The average values of water quality parameters in samples taken from different lake areas are shown in Table 3. Nutrient loads (TN and TP) are observed to be higher in Zhushan Bay and western lake than in the other lake regions, especially in Zhushan Bay where TN and TP are about 160 and $200 \%$ of the average of the whole samples, but DO is 
Fig. 7 Average values of fluorescence indices for water samples from different lake areas. a Biological index (BIX); b humification index (HIX)
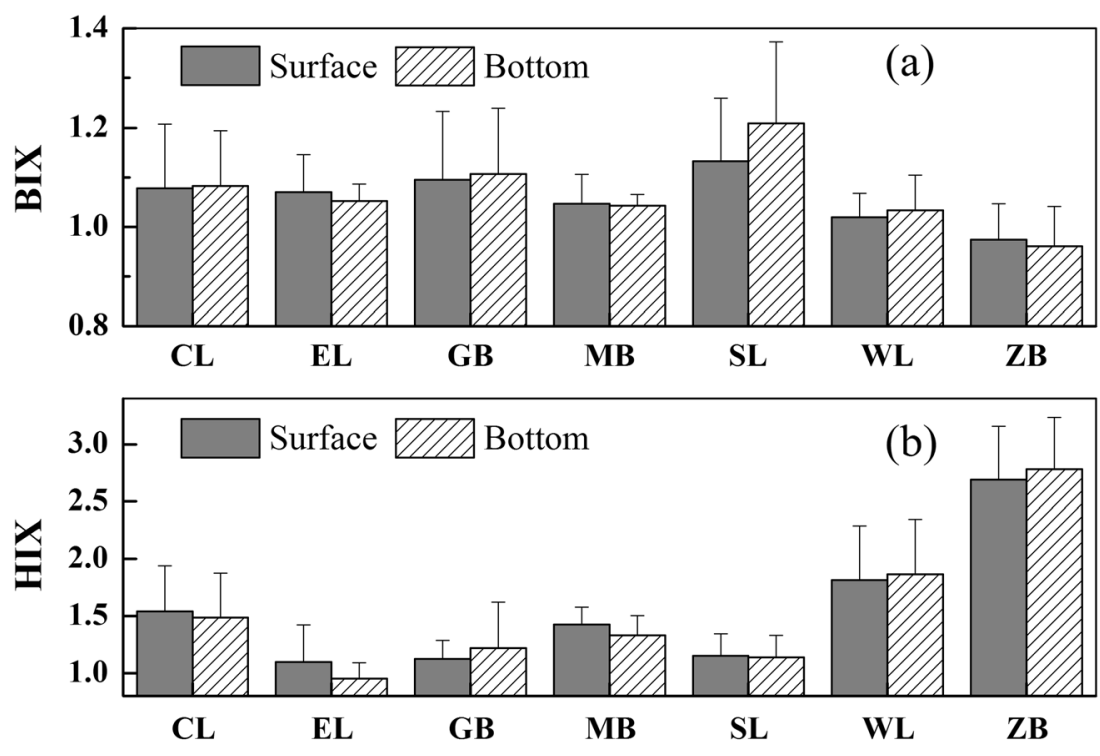

Lake Area only $60 \%$ of the average, suggesting heavier organic pollution. The vertical variations of the water quality parameters are less significant than their horizontal differences. In general, TN and DO in the surface samples are a little higher than those in the bottom water samples, but TP has the opposite trend.

The correlation between the six components and five water quality parameters were analyzed by the Pearson productmoment correlation method (Liu et al. 2004), and the determined coefficient as well as significance level of the linear relationships for the water samples from the surface and bottom layers are provided in Table 4 and Table 5, respectively. Positive and significant linear relationships are found between the fluorescent components and nutrients (TN, TP) in the water, especially for $\mathrm{C} 1, \mathrm{C} 2, \mathrm{C} 5$, and $\mathrm{C} 6$, which have higher positive coefficients $(0.46-0.62, p<0.001)$ with TP. Strong negative linear relationships exist between the fluorescent components and DO, with coefficient values ranging from
-0.73 to -0.34 , which are mainly due to DO consumptions from biological degradations of CDOM.

\section{Discussions}

\section{Influence of sources}

The spatial distribution of CDOM in lakes is influenced by multiple factors, such as sources (allochthonous and/or autochthonous) and biogeochemical transformations (photochemical and/or biological degradation) (Henderson et al. 2008, Yao et al. 2011).

It is found in this study and previous reports (Zhang et al. 2011, Zhou et al. 2015a) that areas with relatively high CDOM concentrations are mainly located in the northern and northwestern parts of Lake Taihu (Zhushan Bay, western

Table 3 Average values of water quality parameters in samples from different lake areas

\begin{tabular}{|c|c|c|c|c|c|c|c|c|c|c|}
\hline \multirow[t]{2}{*}{ Lake areas } & \multicolumn{2}{|c|}{$\mathrm{TN}(\mathrm{mg} / \mathrm{L})$} & \multicolumn{2}{|c|}{ TDN (mg/L) } & \multicolumn{2}{|c|}{$\mathrm{TP}(\mathrm{mg} / \mathrm{L})$} & \multicolumn{2}{|c|}{ DOC (mg/L) } & \multicolumn{2}{|c|}{$\mathrm{DO}(\mathrm{mg} / \mathrm{L})$} \\
\hline & Surface & Bottom & Surface & Bottom & Surface & Bottom & Surface & Bottom & Surface & Bottom \\
\hline Center lake & 4.59 & 5.01 & 1.98 & 1.98 & 0.059 & 0.063 & 15.1 & 14.5 & 7.7 & 7.6 \\
\hline Eastern lake & 4.39 & 4.08 & 1.65 & 1.66 & 0.042 & 0.047 & 14.5 & 17.7 & 8.0 & 7.8 \\
\hline Gonghu Bay & 4.75 & 4.70 & 1.46 & 1.35 & 0.051 & 0.055 & 16.1 & 15.6 & 8.9 & 8.1 \\
\hline Meiliang Bay & 3.89 & 3.85 & 1.60 & 1.90 & 0.088 & 0.088 & 12.3 & 15.2 & 8.0 & 7.4 \\
\hline Southern lake & 3.75 & 3.57 & 2.14 & 2.13 & 0.044 & 0.050 & 15.8 & 16.6 & 8.0 & 8.0 \\
\hline Western lake & 4.98 & 4.44 & 2.09 & 2.02 & 0.066 & 0.065 & 14.2 & 13.2 & 7.2 & 7.0 \\
\hline Zhushan Bay & 7.81 & 7.81 & 2.94 & 3.18 & 0.134 & 0.133 & 10.4 & 13.9 & 4.5 & 4.3 \\
\hline Average & 4.80 & 4.68 & 1.97 & 1.98 & 0.064 & 0.067 & 14.4 & 14.9 & 7.5 & 7.3 \\
\hline
\end{tabular}

$T N$ total nitrogen, $T D N$ total dissolved nitrogen, $T P$ total phosphorus, $D O$ dissolved oxygen, $D O C$ dissolved organic carbon 
Table 4 Correlation coefficient and significance level between the six fluorescent components (C1-C6) and water quality parameters for surface water samples

\begin{tabular}{|c|c|c|c|c|c|c|c|c|c|c|c|}
\hline & $\mathrm{C} 1$ & $\mathrm{C} 2$ & $\mathrm{C} 3$ & $\mathrm{C} 4$ & $\mathrm{C} 5$ & C6 & DO & $\mathrm{TN}$ & TDN & $\mathrm{TP}$ & DOC \\
\hline $\mathrm{C} 1$ & 1.00 & - & - & - & - & - & - & - & - & - & - \\
\hline $\mathrm{C} 2$ & $0.79 *$ & 1.00 & - & - & - & - & - & - & - & - & - \\
\hline $\mathrm{C} 3$ & $0.55^{*}$ & $0.50 *$ & 1.00 & - & - & - & - & - & - & - & - \\
\hline $\mathrm{C} 4$ & $0.74 *$ & $0.71 *$ & $0.75^{*}$ & 1.00 & - & - & - & - & - & - & - \\
\hline $\mathrm{C} 5$ & $0.76^{*}$ & $0.75 *$ & $0.75^{*}$ & $0.61 *$ & 1.00 & - & - & - & - & - & - \\
\hline C6 & $0.49^{*}$ & $0.45^{*}$ & $0.67 *$ & $0.44^{*}$ & $0.78^{*}$ & 1.00 & - & - & - & - & - \\
\hline DO & $-0.68^{*}$ & $-0.67 *$ & $-0.53 *$ & $-0.49 *$ & $-0.73 *$ & $-0.70^{*}$ & 1.00 & - & - & - & - \\
\hline $\mathrm{TN}$ & $0.33^{*}$ & $0.34 *$ & $0.26 * * *$ & 0.11 & $0.44 *$ & $0.36^{*}$ & $-0.41 *$ & 1.00 & - & - & - \\
\hline TDN & $0.32 * *$ & $0.30 * *$ & $0.21 * * *$ & $0.21 * * *$ & $0.37 *$ & $0.42^{*}$ & $-0.41 *$ & $0.34 *$ & 1.00 & - & - \\
\hline $\mathrm{TP}$ & $0.62^{*}$ & $0.60 *$ & $0.34^{*}$ & $0.29 *$ & $0.59 *$ & $0.59 *$ & $-0.56^{*}$ & $0.30 * *$ & $0.33^{*}$ & 1.00 & - \\
\hline DOC & $0.78^{*}$ & $0.75^{*}$ & $0.69 *$ & $0.67^{*}$ & $0.74 *$ & $0.61 *$ & $-0.64 *$ & $0.24 * * *$ & $0.29 * *$ & $0.48 * *$ & 1.00 \\
\hline
\end{tabular}

$T N$ total nitrogen, $T D N$ total dissolved nitrogen, $T P$ total phosphorus, $D O$ dissolved oxygen, $D O C$ dissolved organic carbon $* p<0.001 ; * * p<0.005 ; * * * p<0.05$

lake, and Meiliang Bay). Remarkable declines in fluorescence intensities of CDOM components (e.g., $\mathrm{C} 1$ and $\mathrm{C} 6$ ) are observed from the north and northwest to the center and then to the south and southeast of the lake (see Fig. 5). Outputs from analysis on fluorescence indices show that these areas have larger HIX and smaller BIX values than the other lake areas, suggesting stronger allochthonous CDOM characteristics, and terrestrial inputs from rivers and tributaries may be the dominant sources (Zsolnay et al. 1999; McKnight et al. 2001; Huguet et al. 2009; Birdwell and Engel 2010; Zhou et al. 2015a). The results are in accordance with those in previous reports (Zhang et al. 2011, Zhou et al. 2015a). In fact, the northern and northwestern sub-basins are covered by highly urbanized towns with high population density (Qin et al. 2010). Most of the heavily polluted rivers such as Caoqiao
R., Liangxi R., Taige R., Yicun R., and Zhihugang R. are located in these regions, and huge amounts of DOM as well as nutrients derived from sewage, industry waste, and domestic effluents with little or no treatments are discharged into the rivers and come into the lake, making these lake areas exhibit stronger allochthonous CDOM characteristics than the other areas (Yao et al. 2011, Zhang et al. 2011, Zhou et al. 2015c).

In addition to terrestrial sources, materials mainly derived from in situ decomposition of phytoplankton and macrophyte may also be an important contributor to the CDOM pool in large, shallow, and eutrophic lakes (Zhang et al. 2009a; Birdwell and Engel 2010; Osburn et al. 2011). Lake Taihu has a very large surface area and a long water retention time; therefore, it essentially serves not only as a sink but also a large biological reactor for CDOM (Zhou et al. 2015c). In

Table 5 Correlation coefficient and significance level between the six fluorescent components (C1-C6) and water quality parameters for bottom water samples

\begin{tabular}{|c|c|c|c|c|c|c|c|c|c|c|c|}
\hline & $\mathrm{C} 1$ & $\mathrm{C} 2$ & $\mathrm{C} 3$ & $\mathrm{C} 4$ & $\mathrm{C} 5$ & $\mathrm{C} 6$ & DO & $\mathrm{TN}$ & TDN & $\mathrm{TP}$ & DOC \\
\hline $\mathrm{C} 1$ & 1.00 & - & - & - & - & - & - & - & - & - & - \\
\hline $\mathrm{C} 2$ & $0.78^{*}$ & 1.00 & - & - & - & - & - & - & - & - & - \\
\hline $\mathrm{C} 3$ & $0.52 *$ & $0.47^{*}$ & 1.00 & - & - & - & - & - & - & - & - \\
\hline $\mathrm{C} 4$ & $0.65^{*}$ & $0.65^{*}$ & $0.79 *$ & 1.00 & - & - & - & - & - & - & - \\
\hline $\mathrm{C} 5$ & $0.75^{*}$ & $0.73 *$ & $0.71 *$ & $0.56^{*}$ & 1.00 & - & - & - & - & - & - \\
\hline C6 & $0.49 *$ & $0.43 *$ & $0.60 *$ & $0.36^{*}$ & $0.76^{*}$ & 1.00 & - & - & - & - & - \\
\hline DO & $-0.67 *$ & $-0.64 *$ & $-0.45^{*}$ & $-0.34^{*}$ & $-0.69^{*}$ & $-0.77 *$ & 1.00 & - & - & - & - \\
\hline $\mathrm{TN}$ & $0.34 *$ & 0.33 & $0.40 * * *$ & $0.24 * * *$ & $0.43^{*}$ & $0.36^{*}$ & $-0.41 *$ & 1.00 & - & - & - \\
\hline TDN & 0.17 & $0.16^{*}$ & 0.16 & 0.09 & $0.28 * * *$ & $0.46^{*}$ & $-0.44 *$ & $0.30 * *$ & 1.00 & - & - \\
\hline $\mathrm{TP}$ & $0.47 *$ & $0.46^{*}$ & $0.28 * * *$ & $0.20 * * *$ & $0.50^{*}$ & $0.54 *$ & $-0.60 *$ & $0.33^{*}$ & $0.37 *$ & 1.00 & - \\
\hline DOC & $0.78^{*}$ & $0.75^{*}$ & $0.62 *$ & $0.58 *$ & $0.72 *$ & $0.59 *$ & $-0.66^{*}$ & $0.39 *$ & $0.25^{*}$ & $0.38^{*}$ & 1.00 \\
\hline
\end{tabular}

$T N$ total nitrogen, $T D N$ total dissolved nitrogen, $T P$ total phosphorus, $D O$ dissolved oxygen, $D O C$ dissolved organic carbon

$* p<0.001 ; * * p<0.005 ; * * * p<0.05$ 


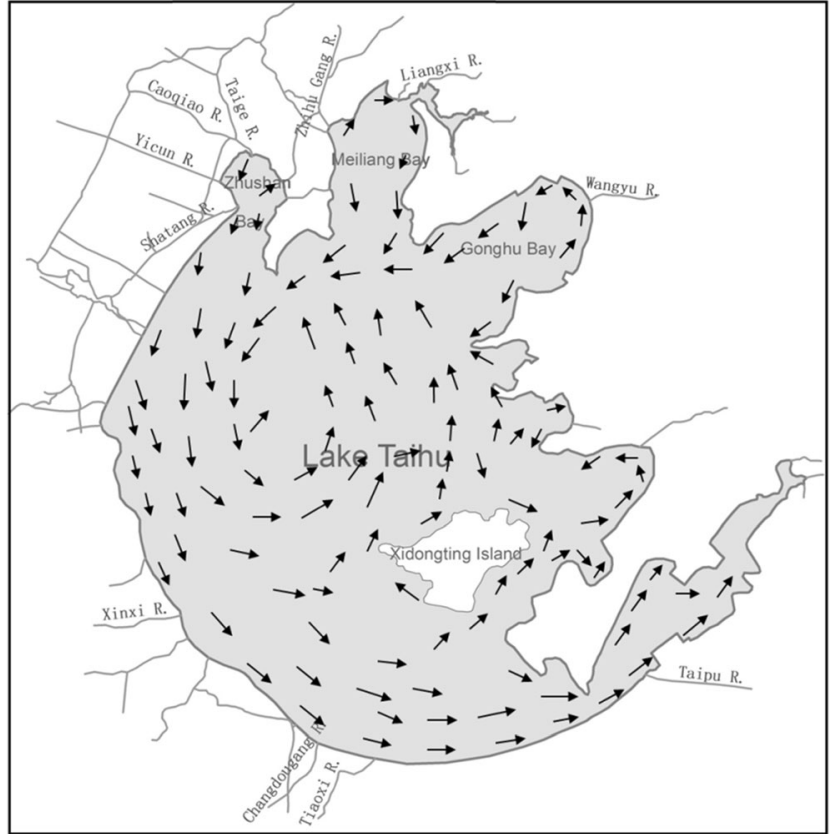

Fig. 8 Vector plots of flow fields at the water surface in Lake Taihu under prevailing south and southwest (SSW) winds (which usually dominated from June to September), according to Qin et al. (2007)

recent decades, heavy cyanobacterial blooms induced by high nutrient loads of nitrogen and phosphorous have occurred in Lake Taihu, especially in the northern and northwestern areas where blooms have taken place almost every year (Zhang et al. 2011, Zhou et al. 2015a). Large quantities of biomass were produced during the blooms and degraded by microorganisms after the death of phytoplankton. As a result, CDOM in these regions (such as Meiliang Bay, Gonghu Bay, and western lake) also exhibit stronger autochthonous characteristics than the other lake areas, and relatively higher fluorescence

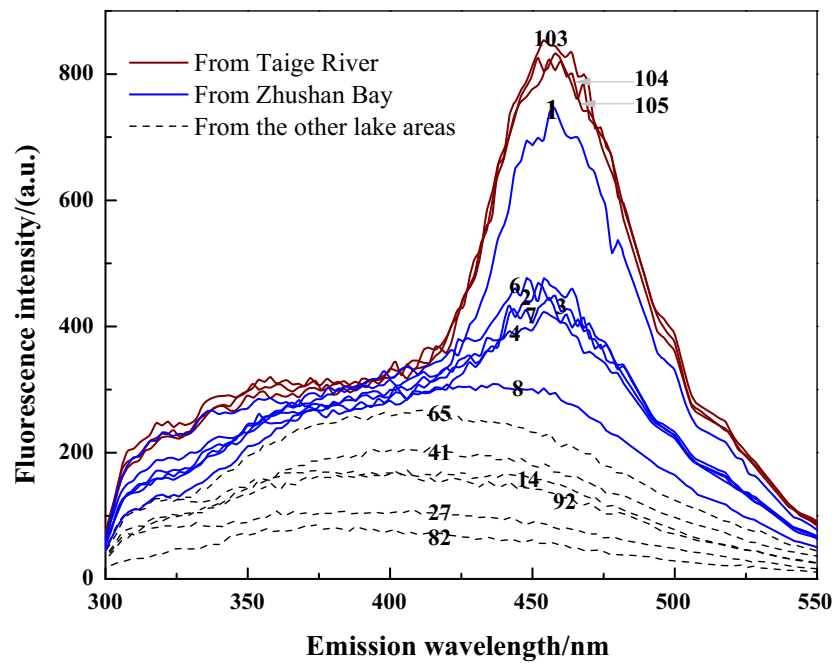

Fig. 9 Emission spectra at exciting wavelength of $255 \mathrm{~nm}$ for water samples from different areas including three samples from the Taige River connected to Zhushan Bay. Numbers are identifiers for the sampling sites shown in Fig. 1

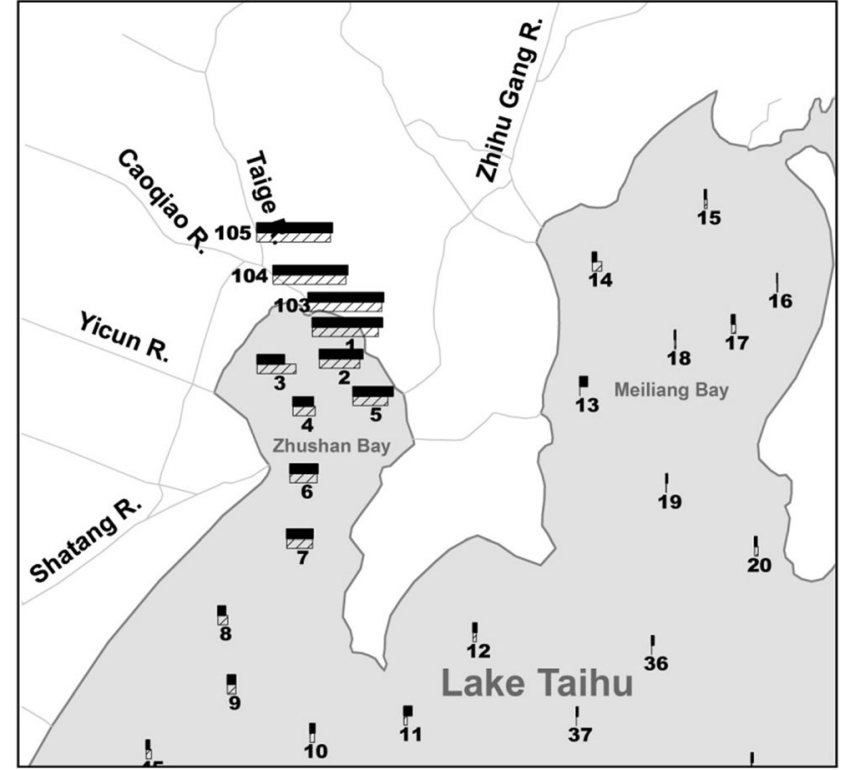

Fig. 10 Bar chart for spatial distribution of component $\mathrm{C} 6$ in the north of Lake Taihu (including three samples from the Taige River). Horizontal bars represented fluorescence maxima calculated by the PARAFAC model (Fmax, in unit of a.u.) of each sampling site, in which black and line-filled bars stood for water samples from surface and bottom layer, respectively. Numbers are identifiers for sampling sites shown in Fig. 1

intensities of component $\mathrm{C} 2$, which is probably derived from phytoplankton degradation, are found in these regions. In contrast, the eastern and southern lake areas are cleaner (with lower nutrient loads in the water) and less affected by algal blooms, where eastern lake is far away from the regions with heavy algal blooms described above and southern lake is dominated by macrophytes. Therefore, relatively lower intensities of $\mathrm{C} 2$ are observed in these areas.

\section{Influence of hydrodynamic conditions}

Hydrodynamic conditions also play important roles in shaping the spatial pattern of CDOM in the water (Wu et al. 2015, Zhou et al. 2016b). In Lake Taihu, no obvious temperature stratifications are found (Qin et al. 2007), and wind-induced waves and currents are the major forces transporting materials both horizontally and vertically, which can not only directly transport CDOM from one region to another but can also have indirect effects through altering the distributions of nutrients and phytoplankton. Previous studies (Qin et al. 2007) found that prevailing winds from the southeast or southwest during the summer season (usually from June to September) could generate a large counterclockwise circumfluence in the center of Lake Taihu, and there was a stable southward current along the western coast and a weak and unstable current in Meiliang Bay (see Fig. 8). As described before, most of the rivers and channels (especially those heavily polluted) are located in the north and west, and water mainly goes out through Taipu River in the southeast of the lake. Therefore, DOM discharged 
into the lake from these rivers will be carried by the southward current and then transported along the west coast from north to south, and part of it will be brought to the center and the east by the large counterclockwise circumfluence. This can be clearly seen on the contour maps of the terrestrial fluorescent components (e.g., $\mathrm{C} 1$ and C6, shown in Fig. 5), in which the shapes of contours suggest a very similar transporting trajectory of DOM by the currents. Also, the currents could lead to an aggregation of algal blooms (Microcystis spp.) in the northern and northwestern regions of the lake, making these areas algae-dominated and exhibit stronger autochthonous characteristics (larger $F_{\max }$ values of $\mathrm{C} 2$ ) than the other regions.

Vertically, the mixing of CDOM in the water column is mainly controlled by hydrodynamic process. There are almost no density flows in such a large, shallow, and freshwater lake, as minor and transient thermal stratification is easily broken down by the wind (Tao et al. 2007). Therefore, waves and currents induced by wind become the dominant factors, and the mixing strength is determined by wind speed. Materials such as CDOM, nutrients, and algae in the water column tend to be uniformly distributed by turbulent mixing under strong wind conditions, especially in the bays and the western coastal regions where the water is relatively shallow (Wu \& Kong 2009). As a result, only about $6 \%$ difference is observed in the average $F_{\max }$ values between the water samples from the surface and bottom layers, and the CV values are smaller in the northern and western regions. However, the vertical heterogeneity of CDOM characteristics is still noticeable, as the CV values ranged from 0.04 to $141 \%$ among distinct components and sampling sites. In addition, $F_{\max }$ values of the surface water samples are generally smaller than those of the bottom samples, which may be due to two aspects: (1) photochemical degradation of CDOM in the surface layer is stronger than that in the bottom, as solar radiation is more intensive at the water surface. Photochemical degradation can result in significant alternations of florescence properties, absorbance losses, decreases in aromaticity and average molecular weight of CDOM, as well as declines in DOC concentration in the water (Zhang et al. 2009b; Zhang et al. 2013; Zhang et al. 2015); (2) resuspension from sediment by wind-induced waves and currents may increase CDOM concentration of the bottom water. Sediment is an important sink as well as source in Lake Taihu (Hu et al. 2012). Wind-induced hydrodynamic disturbance can result in explosive sediment suspension and release of CDOM from the sediment to the overlying water (Wu et al. 2015).

Interestingly, the observed average $\mathrm{TN}$ concentration in the surface water samples is a little larger than that in the bottom samples. It may be partially explained by the amount of algal biomass being greater in the surface water samples, as previous observations in Lake Taihu by Wu and Kong (2009) suggested that the cyanobacteria Microcystis spp. colonies (especially those with a radius larger than $120 \mu \mathrm{m}$ ) were mainly concentrated in the surface layers (at 0 and $0.5 \mathrm{~m}$ ) under calm, even windy, conditions.

\section{Sources and indications of component C6}

It is very interesting to find that $\mathrm{C} 6$ seems to be unique in water samples from Zhushan Bay and exhibits strong terrestrial characteristics. The fluorescence intensity of C6 exhibits sharp declines from the northern end to the open area of Zhushan Bay and becomes much lower outside the bay (see Fig. 5f), suggesting an obvious dispersion trajectory that is in agreement with the wind-induced current shown in Fig. 8. Although the other components (e.g., C1, C2) have similar spatial patterns and transporting characteristics as well, the horizontal heterogeneity of $\mathrm{C} 6$ is much greater between the inside and outside areas of Zhushan Bay. In addition, the emission spectra excited at the wavelength of $255 \mathrm{~nm}$ (i.e., the exciting wavelength of C6's $F_{\max }$ ) show that the water samples collected from Zhushan Bay are different to those collected from the other lake areas (see Fig. 9), in which there are intense peaks at the emission wavelength of about $455 \mathrm{~nm}$ (i.e., the emission wavelength of C6's $F_{\max }$ ). Such peaks are also found in the spectra (Fig. 9) of the samples obtained from the Taige River which connects to the northern end of Zhushan Bay, suggesting that C6 probably originates from riverine inputs.

A spatially distributed bar plot (i.e., to plot bars at the locations of the sampling sites) for the $F_{\max }$ values of C6 is shown in Fig. 10, from which it can be seen that site no. 1 in Zhushan Bay, which is closest to the mouth of the Taige River, has a similar $F_{\max }$ value to those of the three sites (nos. 103105) in the upstream of the Taige River, and sharp declines with increasing distances from the river mouth are observed at the other sites in the bay (nos. 2-8). Therefore, we infer that C6 is mainly from the discharge of the Taige River (may also be sourced from Caoqiao River which has the same mouth to flow into Zhushan Bay, but water samples from this river were unavailable in the present study). Although there are no samples available in the other rivers (such as Yicun R. and Shatang R.) connected to Zhushan Bay, it could still be inferred that these rivers were not likely to be the major sources of 66 , as no obvious gradients of $F_{\max }$ values were found at the sites (such as site nos. 3 and 5) near the mouths of these rivers.

C6 is not likely to be derived from degradation of algae either. Meiliang Bay usually has heavier cyanobacterial blooms than the other lake areas due to its high nutrient loads and hydrodynamic conditions (Qin et al. 2007). However, the $F_{\max }$ values of $\mathrm{C} 6$ in the water samples from this region are significantly lower. In addition, the excitation and emission characteristics of $\mathrm{C} 6$ are more prone to be terrestrial-like according to previous studies (Stedmon and Markager 2005a; Yamashita et al. 2008; Osburn et al. 2011; Chari et al. 2012). 
The unique characteristics of C6 make it a potential indicator of "point source" discharge of CDOM in Lake Taihu, and its spatial pattern could be a representative of CDOM discharged from the Taige River. It may also be used as an environmental tracer to study the transportation process of CDOM discharged from the Taige River.

\section{Conclusions}

(1) Six fluorescent components (named C1-C6) were identified through PARAFAC analysis, consisting of four humiclike and two protein-like CDOM signatures.

(2) Clearly larger $F_{\max }$ values (especially for $\mathrm{C} 1, \mathrm{C} 2$, and C6) were found in the northern and western regions, with notable declines to the center and then to the eastern and southern areas, suggesting transporting trajectories in accordance with the wind-induced currents under prevailing wind conditions.

(3) The average $F_{\max }$ value of the surface water samples was about $6 \%$ less than that of the bottom samples. However, the vertical heterogeneity of CDOM characteristics is still noticeable considering the large variations of $\mathrm{CV}$ values among distinct components and sites.

(4) The spatial variations of BIX and HIX values suggested stronger allochthonous CDOM characteristics in Zhushan Bay and Western Lake and autochthonous characteristics in southern lake and eastern lake.

(5) Component C6 was unique in Zhushan Bay and probably originated from the discharge of the Taige River. Its unique nature and source make it a potential indictor and tracer to CDOM fate from point-source discharge.

Acknowledgments This study was financially supported by the National Natural Science Foundation of China (11202217). We are also very grateful for the reviewers' professional and detailed comments which are very helpful for us to improve the quality of our work.

\section{References}

Biers EJ, Zepp RG, Moran MA (2007) The role of nitrogen in chromophoric and fluorescent dissolved organic matter formation. Mar Chem 103:46-60. doi:10.1016/j.marchem.2006.06.003

Birdwell JE, Engel AS (2010) Characterization of dissolved organic matter in cave and spring waters using UV-vis absorbance and fluorescence spectroscopy. Org Geochem 41:270-280. doi:10.1016/j. orggeochem.2009.11.002

Chari NVHK, Sarma NS, Pandi SR, Murthy KN (2012) Seasonal and spatial constraints of fluorophores in the midwestern Bay of Bengal by PARAFAC analysis of excitation emission matrix spectra. Estuar Coast Shelf Sci 100:162-171. doi:10.1016/j.ecss.2012.01.012

Coble PG (1996) Characterization of marine and terrestrial DOM in seawater using excitation-emission matrix spectroscopy. Mar Chem 51: 325-346. doi:10.1016/0304-4203(95)00062-3
Coble PG, Del Castillo CE, Avril B (1998) Distribution and optical properties of CDOM in the Arabian Sea during the 1995 southwest monsoon. Deep-Sea Res II Top Stud Oceanogr 45:2195-2223. doi:10.1016/s0967-0645(98)00068-x

Henderson RK, Baker A, Parsons SA, Jefferson B (2008) Characterisation of algogenic organic matter extracted from cyanobacteria, green algae and diatoms. Water Res 42:3435-3445. doi:10.1016/j.watres.2007.10.032

Hood E, Fellman J, Spencer RG, Hernes PJ, Edwards R, D'Amore D, Scott D (2009) Glaciers as a source of ancient and labile organic matter to the marine environment. Nature 462:1044-1047. doi:10.1038/nature08580

Hu C, Yuan Z, Tao Y, Bo Y (2012) Spectroscopy characteristics and environmental implications of dissolved organic matters in the sediment of Taihu Lake, China. Fresenius Environ Bull 21:976-985

Huguet A, Vacher L, Relexans S, Saubusse S, Froidefond JM, Parlanti E (2009) Properties of fluorescent dissolved organic matter in the Gironde estuary. Org Geochem 40:706-719. doi:10.1016/j. orggeochem.2009.03.002

Jørgensen L, Stedmon CA, Kragh T, Markager S, Middelboe M, Søndergaard M (2011) Global trends in the fluorescence characteristics and distribution of marine dissolved organic matter. Mar Chem 126:139-148. doi:10.1016/j.marchem.2011.05.002

Liu Y, Meng Q, Chen R, Wang J, Jiang S, Hu Y (2004) A new method to evaluate the similarity of chromatographic fingerprints: weighted Pearson product-moment correlation coefficient. J Chromatogr Sci 42:545-550. doi:10.1093/chromsci/42.10.545

McKnight DM, Boyer EW, Westerhoff PK, Doran PT, Kulbe T, Andersen DT (2001) Spectrofluorometric characterization of dissolved organic matter for indication of precursor organic material and aromaticity. Limnol Oceanogr 46:38-48. doi:10.4319/lo.2001.46.1.0038

Mobed JJ, Hemmingsen SL, Autry JL, McGown LB (1996) Fluorescence characterization of IHSS humic substances: total luminescence spectra with absorbance correction. Environ Sci Technol 30:3061-3065. doi:10.1021/es9601321

Murphy KR, Stedmon CA, Graeber D, Bro R (2013) Fluorescence spectroscopy and multi-way techniques. PARAFAC. Anal Methods 5: 38-65. doi:10.1039/c3ay41160e

Murphy KR, Stedmon CA, Waite TD, Ruiz GM (2008) Distinguishing between terrestrial and autochthonous organic matter sources in marine environments using fluorescence spectroscopy. Mar Chem 108: 40-58. doi:10.1016/j.marchem.2007.10.003

Nimptsch J, StefanWoelfl OS, Valenzuela J, Ebersbach P, Tümpling WV, Palma R, Encina F, Figueroa D, Kamjunke N (2015) Tracing dissolved organic matter (DOM) from land-based aquaculture systems in North Patagonian streams. Sci Total Environ 537:129-138. doi:10.1016/j.scitotenv.2015.07.160

Osburn CL, Wigdahl CR, Fritz SC, Saros JE (2011) Dissolved organic matter composition and photoreactivity in prairie lakes of the U.S. Great Plains. Limnol Oceanogr 56:2371-2390. doi:10.4319/lo.2011.56.6.2371

Qin B, Zhu G, Gao G, Zhang Y, Li W, Paerl HW, Carmichael WW (2010) A drinking water crisis in Lake Taihu, China: linkage to climatic variability and lake management. Environ Manag 45:105-112. doi:10.1007/s00267-009-9393-6

Qin BQ, PZ X, QL W, Luo LC, Zhang YL (2007) Environmental issues of Lake Taihu, China. Hydrobiologia 581:3-14. doi:10.1007/s10750-0060521-5

Stedmon CA, Markager S (2005a) Tracing the production and degradation of autochthonous fractions of dissolved organic matter by fluorescence analysis. Limnol Oceanogr 50:1415-1426. doi:10.4319 $/ 10.2005 .50 .5 .1415$

Stedmon CA, Markager S (2005b) Resolving the variability in dissolved organic matter fluorescence in a temperate estuary and its catchment using PARAFAC analysis. Limnol Oceanogr 50:686-697. doi:10.4319/lo.2005.50.2.0686 
Stedmon CA, Markager S, Bro R (2003) Tracing dissolved organic matter in aquatic environments using a new approach to fluorescence spectroscopy. Mar Chem 82:239-254. doi:10.1016/S0304-4203(03)00072-0

Tao L, Wang D, Zhang B, Liu H, Tang H (2007) Morphological characterization of suspended particles under wind-induced disturbance in Taihu Lake, China. Environ Monit Assess 127:79-86. doi:10.1007 /s10661-006-9261-2

Williams CJ, Yamashita Y, Wilson HF, Jaffé R, Xenopoulos MA (2010) Unraveling the role of land use and microbial activity in shaping dissolved organic matter characteristics in stream ecosystems. Limnol Oceanogr 55:1159-1171. doi:10.4319/lo.2010.55.3.1159

Wu T, Wang Z, Niu C, Zhang Y, Li B, Li P (2015) The effect of intense hydrodynamic disturbance on chromophoric dissolved organic matter in a shallow eutrophic lake. J Freshw Ecol 30:143-156. doi: $10.1080 / 02705060.2014 .961043$

Wu X, Kong F (2009) Effects of light and wind speed on the vertical distribution of Microcystis aeruginosa colonies of different sizes during a summer bloom. Int Rev Hydrobiol 94:258-266. doi:10.1002/iroh.200811141

Yamashita Y, Jaffé R, Maie N, Tanoue E (2008) Assessing the dynamics of dissolved organic matter (DOM) in coastal environments by excitation emission matrix fluorescence and parallel factor analysis (EEM-PARAFAC). Limnol Oceanogr 53:1900-1908. doi:10.4319 /lo.2008.53.5.1900

Yang H, Shen Z, Zhu S, Wang W (2007) Vertical and temporal distribution of nitrogen and phosphorus and relationship with their influencing factors in aquatic-terrestrial ecotone: a case study in Taihu Lake, China. J Environ Sci 19:689-695. doi:10.1016/s1001-0742(07)60115-6

Yao X, Zhang Y, Zhu G, Qin B, Feng L, Cai L, Gao G (2011) Resolving the variability of CDOM fluorescence to differentiate the sources and fate of DOM in Lake Taihu and its tributaries. Chemosphere 82:145-155. doi:10.1016/j.chemosphere.2010.10.049

Zhang Y, Gao G, Shi K, Niu C, Zhou Y, Qin B, Liu X (2014) Absorption and fluorescence characteristics of rainwater CDOM and contribution to Lake Taihu, China. Atmos Environ 98:483-491. doi:10.1016/j.atmosenv.2014.09.038

Zhang Y, Hu C, Yu T (2015) Photodegradation of chromophoric dissolved organic matters in the water of Lake Dianchi, China. Front Environ Sci Eng 9:575-582. doi:10.1007/s11783-014-0664-y

Zhang Y, Liu M, Qin B, Feng S (2009b) Photochemical degradation of chromophoric-dissolved organic matter exposed to simulated UV-B and natural solar radiation. Hydrobiologia 627:159-168. doi:10.1007/s10750-009-9722-z

Zhang Y, Liu X, Osburn CL, Wang M, Qin B, Zhou Y (2013) Photobleaching response of different sources of chromophoric dissolved organic matter exposed to natural solar radiation using absorption and excitation-emission matrix spectra. PLoS One 8: e77515. doi:10.1371/journal.pone.0077515

Zhang Y, van Dijk MA, Liu M, Zhu G, Qin B (2009a) The contribution of phytoplankton degradation to chromophoric dissolved organic matter (CDOM) in eutrophic shallow lakes: field and experimental evidence. Water Res 43:4685-4697. doi:10.1016/j. watres.2009.07.024

Zhang Y, Yin Y, Liu X, Shi Z, Feng L, Liu M, Zhu G, Gong Z, Qin B (2011) Spatial-seasonal dynamics of chromophoric dissolved organic matter in Lake Taihu, a large eutrophic, shallow lake in China. Org Geochem 42:510-519. doi:10.1016/j.orggeochem.2011.03.007

Zhou Y, Zhang Y, Shi K, Liu X, Niu C (2015a) Dynamics of chromophoric dissolved organic matter influenced by hydrological conditions in a large, shallow, and eutrophic lake in China. Environ Sci Pollut Res Int 22:12992-13003. doi:10.1007/s11356-015-4556-x

Zhou Y, Zhang Y, Shi K, Niu C, Liu X, Duan H (2015c) Lake Taihu, a large, shallow and eutrophic aquatic ecosystem in China serves as a sink for chromophoric dissolved organic matter. J Great Lakes Res 41:597-606. doi:10.1016/j.jglr.2015.03.027

Zhou Y, Jeppesen E, Zhang Y, Niu C, Shi K, Liu X, Zhu G, Qin B (2015b) Chromophoric dissolved organic matter of black waters in a highly eutrophic Chinese lake: freshly produced from algal scums? J Hazard Mater 299:222-230. doi:10.1016/j.jhazmat.2015.06.024

Zhou Y, Jeppesen E, Zhang Y, Shi K, Liu X, Zhu G (2016a) Dissolved organic matter fluorescence at wavelength $275 / 342 \mathrm{~nm}$ as a key indicator for detection of point-source contamination in a large Chinese drinking water lake. Chemosphere 144:503-509. doi:10.1016/j.chemosphere.2015.09.027

Zhou Y, Zhou J, Jeppesen E, Zhang Y, Qin B, Shi K, Tang X, Han X (2016b) Will enhanced turbulence in inland waters result in elevated production of autochthonous dissolved organic matter? Sci Total Environ 543 :405-415. doi:10.1016/j.scitotenv.2015.11.051Part A

Zsolnay A, Baigar E, Jimenez M, Steinweg B, Saccomandi F (1999) Differentiating with fluorescence spectroscopy the sources of dissolved organic matter in soils subjected to drying. Chemosphere 38: 45-50. doi:10.1016/S0045-6535(98)00166-0 